\title{
Response of photosynthesis and chlorophyll fluorescence to acute ozone stress in tomato (Solanum lycopersicum Mill.)
}

\author{
A.A. THWE ${ }^{\#,+}$, G. VERCAMBRE ${ }^{*}$, H. GAUTIER ${ }^{*}$, F. GAY $^{* *}$, J. PHATTARALERPHONG $^{* * *}$, and \\ P. KASEMSAP ${ }^{+}$
}

Department of Horticulture, Yezin Agricultural University, 05282 Nay Pyi Taw, Myanmar ${ }^{\#}$

INRA, UR 1115, Plantes et Systèmes de culture Horticoles, Domaine St. Paul, Site Agroparc, 228 route de l'Aérodrome CS 40509, F-84914 Avignon, Cedex 9, France*

CIRAD, UMR111 Eco\&Sols, 2 Place Viala, F-34060 Montpellier, France**

Faculty of Natural Resources and Agro-Industry, Kasetsart University Chalermphrakiat Sakon Nakhon

Province Campus, 47000 Thailand ${ }^{* * *}$

Department of Horticulture, Tropical Agriculture, Kasetsart University, 10900 Bangkok, Thailand ${ }^{+}$

\begin{abstract}
The crop sensitivity to ozone $\left(\mathrm{O}_{3}\right)$ is affected by the timing of the $\mathrm{O}_{3}$ exposure, by the $\mathrm{O}_{3}$ concentration, and by the crop age. To determine the physiological response to the acute ozone stress, tomato plants were exposed to $\mathrm{O}_{3}$ at two growth stages. In Experiment I (Exp. I), $\mathrm{O}_{3}\left(500 \mu \mathrm{g} \mathrm{m}^{-3}\right)$ was applied to 30-d-old plants (PL30). In Experiment II (Exp. II), three $\mathrm{O}_{3}$ concentrations $\left(200,350\right.$, and $\left.500 \mu \mathrm{g} \mathrm{m}^{-3}\right)$ were applied to 51-d-old plants (PL51). The time of the treatment was $4 \mathrm{~h}$ $(7: 30-11: 30 \mathrm{~h})$. Photosynthesis and chlorophyll fluorescence measurements were done 4 times (before the exposure; $20 \mathrm{~min}, 20 \mathrm{~h}$, and 2-3 weeks after the end of the treatment) using a LI-COR 6400 photosynthesis meter. The stomatal pore area and stomatal conductance were reduced as the $\mathrm{O}_{3}$ concentration increased. Ozone induced the decrease in the photosynthetic parameters of tomato regardless of the plant age. Both the photosystem (PS) II operating efficiency and the maximum quantum efficiency of PSII photochemistry declined under the ozone stress suggesting that the PSII activity was inhibited by $\mathrm{O}_{3}$. The impaired PSII contributed to the reduced photosynthetic rate. The greater decline of photosynthetic parameters was found in the PL30 compared with the PL51. It proved the age-dependent ozone sensitivity of tomato, where the younger plants were more vulnerable. Ozone caused the degradation of photosynthetic apparatus, which affected the photosynthesis of tomato plants depending on the growth stage and the $\mathrm{O}_{3}$ concentration.
\end{abstract}

\section{Introduction}

Ozone is regarded as one of the most widespread air pollutants around the world and now it is recognized as a global problem (UNECE 2010). Ground-level $\mathrm{O}_{3}$ is formed from the pollutants emitted from vehicle exhausts, industrial production, and photochemical reactions with

the $\mathrm{O}_{3}$ precursors. The elevated $\mathrm{O}_{3}$ concentration is also a growing concern for rapidly developing nations with rising emissions of the $\mathrm{O}_{3}$ precursors from expanding transportation networks (Bell et al. 2006).

Ozone modifies different physiological processes in

Received 30 August 2012, accepted 1 July 2013.

${ }^{+}$Corresponding author and coauthor; phone: (66) 02-942-7623, fax: (66) 02-942-7624, e-mail: ayethwe.phyo07@gmail.com, agrppk@ku.ac.th

Abbreviations: ATP - adenosine triphosphate; ETR - electron transport rate; $\mathrm{F}_{0}$ - minimal fluorescence of the dark-adapted leaf; $\mathrm{F}_{0}{ }^{\prime}$ - minimal fluorescence of the light-adapted leaf; $\mathrm{F}_{\mathrm{m}}$ - maximal fluorescence of the dark-adapted leaf; $\mathrm{F}_{\mathrm{m}}{ }^{\prime}-$ maximal fluorescence of the light-adapted leaf; $\mathrm{F}_{\mathrm{s}}$ - steady-state fluorescence; $g_{\mathrm{s}}$ - stomatal conductance; $\mathrm{J}_{\max }$ - the maximum rate of carboxylation limited by electron transport rate for RuBP generation; NADPH - nicotinamide adenine dinucleotide phosphate; $\mathrm{O}_{200}$ - ozone treatment of $200 \mu \mathrm{g} \mathrm{m}^{-3} ; \mathrm{O}_{350}$ - ozone treatment of $350 \mu \mathrm{g} \mathrm{m}^{-3} ; \mathrm{O}_{500}$ - ozone treatment of $500 \mu \mathrm{g} \mathrm{m}^{-3} ; P_{\max }$ - light-saturated photosynthetic rate; $P_{\mathrm{N}}$ - net photosynthetic rate; PL30 - 30-d-old plants; PL51 - 51-d-old plants; PPFD - photosynthetic photon flux density; PS photosystem; qP - photochemical quenching coefficient; $R_{\mathrm{D}}$ - dark-respiration rate; Rubisco - ribulose-1,5-bisphosphate carboxylase/ oxygenase; $\mathrm{t}_{\mathrm{b}}$ - before $\mathrm{O}_{3}$ treatment; $\mathrm{t}_{2} \mathrm{~m}-20 \mathrm{~min}$ after $\mathrm{O}_{3}$ treatment; $\mathrm{t}_{20 \mathrm{~h}}-20 \mathrm{~h}$ after $\mathrm{O}_{3}$ treatment; $\mathrm{t}_{3 \mathrm{w}}-2-3$ weeks after $\mathrm{O}_{3}$ treatment; TPU - triose phosphate use; $\mathrm{V}_{\mathrm{cmax}}$ - maximum carboxylation velocity of Rubisco; $\alpha$ - initial slope of the light curve at low PPFD; $\Theta$ - curve convexity; $\Phi_{\mathrm{CO} 2}$ - quantum yield of carboxylation rate; $\Phi_{\mathrm{PSII}}$ - effective quantum yield of photosystem II photochemistry. Acknowledgements: The authors thank the Scholarship Foundation (French Embassy - Thailand International Cooperation Agency Thailand Research Fund) for financial support. 
plants: photosynthesis (Nighat et al. 2000, Calatayud et al. 2011), stomata function (Robinson et al. 1998, Singh et al. 2009), plant growth and development (Saitanis and Karandinos 2002, Kharel and Amgain 2010, Mina et al. 2010), and crop productivity (Chen et al. 2008). Ozone enters a leaf through the stomata by a diffusion process and it is quickly destroyed in the cellular wall and plasmalemma (Laisk et al. 1989). Contran and Paoletti (2007) reported that stomata played the main role in $\mathrm{O}_{3}$ uptake as a higher stomatal conductance was related to a larger potential of $\mathrm{O}_{3}$ uptake (Nighat et al. 2000, Paoletti and Grulke, 2010, Yan et al. 2010). Some authors (Reinert and Henderson 1980, Lyons and Barnes 1998) have suggested that the crop sensitivity to $\mathrm{O}_{3}$ might be influenced by the timing of the $\mathrm{O}_{3}$ exposure and a stage of the plant development. In Plantago major L., the increased resistance to $\mathrm{O}_{3}$ was observed in relation to plant age, due to changes in the leaf tissue features (Lyons et al. 1999). The similar, tissue-age-dependent ozone sensitivity was observed in other crops. Young cereals and spinach were more susceptible to $\mathrm{O}_{3}$ compared with mature ones and the sensitive cultivars of sweet corn were not injured since they reached a height of $45 \mathrm{~cm}$ (Hill et al. 1970). In legumes, the plants in the early growth stage were very vulnerable to $\mathrm{O}_{3}$ (Kasana 1991).

Ozone induces a decline of ribulose-1,5-bisphosphate carboxylase/oxygenase (Rubisco) activity and depresses the $\mathrm{CO}_{2}$ fixation rate (Degl'Innocenti et al. 2002b,

\section{Materials and methods}

Study site and crop management practices: Two experiments (Exp. I - August to September 2010; Exp. II November 2010 to February 2011) were carried out at Kasetsart University, Thailand. The soil (30\% sand, 22\% silt, and $48 \%$ clay) was mixed well with decomposed cow dung and burned rice husk in a ratio of 2:1:1 (v/v/v) and the soil mixture was filled into $12.6 \mathrm{~L}$ glass pots. Tomato seeds (Solanum lycopersicum Mill.) var. 'Look Tor' (indeterminate type) were sown directly into the glass pots ( 3 seeds per pot). The glass pots were arranged in a randomized complete block design with five replications. The pots were spaced $60 \mathrm{~cm}$ within the row from center to center and $90 \mathrm{~cm}$ between the rows. When the seeds started to germinate, thinning was done leaving the strongest plant per pot. All plants were grown under the white net house throughout the experimental period. The glass pots were covered with black plastic sheets to protect the root zone from radiation. The white reflective plastic sheets were used over the black sheets to reduce light absorption and hence heating. The experimental setup, cultural practices, and all fertilizer applications used were the same procedures as reported by Thwe et al. (2013).

Ozone exposure: Two closed-top chambers (one for the $\mathrm{O}_{3}$ exposure and one for the control) with dimensions of
Goumenaki et al. 2010). As Rubisco is the important enzyme of the Calvin cycle, the enzyme degradation due to $\mathrm{O}_{3}$ is associated with the reduced potential to consume ribulose-1,5-bisphosphate (RuBP) at this stage of carbon fixation. Since PSI and PSII produce the power to generate ATP and NADPH, which are used in the Calvin cycle (Moore et al. 1995), any impairment of PS by $\mathrm{O}_{3}$ (Carrasco-Rodriguez and del Valle-Tascon 2001) could cause dysfunction of the whole photosynthetic process. Any alteration of the photosynthetic efficiency by $\mathrm{O}_{3}$ could impair the further plant growth and development. The chlorophyll (Chl) fluorescence measurement provides information on light reaction of photosynthesis. It serves as the noninvasive indicator of the photosynthetic apparatus and is therefore very useful for detection of environmental stresses (Guidi et al. 1997, Degl'Innocenti et al. 2002a, Baker and Rosenqvist 2004).

Among the horticultural crops, tomato is an ozonesensitive crop (Iriti et al. 2006), the sensitivity of which can vary according to the plant age and stress conditions. To better understand crop sensitivity to $\mathrm{O}_{3}$, it is important to know the crop response to stress intensity at the specific growth stages. Based on this information, experiments were carried out to determine the impacts of $\mathrm{O}_{3}$ on photosynthesis and $\mathrm{Chl}$ fluorescence parameters in the vegetative and generative growth stages of tomato under three $\mathrm{O}_{3}$ concentrations.

$120 \mathrm{~cm} \times 120 \mathrm{~cm} \times 200 \mathrm{~cm}$ were made from polyethylene clear plastic.

Ozone was supplied for $4 \mathrm{~h}$ (from 7:30 to 11:30 h) by the $\mathrm{O}_{3}$ generator (Model OZ 8010, Ozonic International Co. Ltd., Thailand) and the ambient air, which passed from the cooling pad, was mixed in the ozone chamber. The $\mathrm{O}_{3}$ concentrations inside the chamber were measured by the computerized ozone analyzer (Model 49i, Thermo Fisher Scientific Inc., USA) throughout the fumigation period. The ambient air passing the cooling pad was blown to the control chamber during the fumigation period. The temperature and relative humidity inside and outside the chamber were measured using the USB data logger (OM-EL-USB-2, Omega Engineering, Inc., USA).

In Exp. I, fumigation by $\mathrm{O}_{3}\left(500 \mu \mathrm{g} \mathrm{m}^{-3}\right)$ was applied to PL30 (the vegetative stage). In Exp. II, three concentrations of $\mathrm{O}_{3}\left(200,350\right.$, and $500 \mu \mathrm{g} \mathrm{m}^{-3}$, i.e. $\mathrm{O}_{200}, \mathrm{O}_{350}$, and $\mathrm{O}_{500}$, respectively) were given to PL51 (the generative stage bearing some trusses and fruits).

Leaf photosynthesis measurement: The leaf photosynthetic rate was measured four times: before the $\mathrm{O}_{3}$ exposure $\left(\mathrm{t}_{\mathrm{b}}\right), 20 \mathrm{~min}\left(\mathrm{t}_{20 \mathrm{~m}}\right), 20 \mathrm{~h}\left(\mathrm{t}_{20 \mathrm{~h}}\right)$, and $2-3$ weeks $\left(\mathrm{t}_{3 \mathrm{w}}\right)$ after the $\mathrm{O}_{3}$ fumigation. The photosynthesis meter (LI-COR 6400, LI-COR Inc., Lincoln, NE, USA) was used 
for Exp. I and the LI-COR 6400 in addition with a fluorescence meter (LI-COR 6400 - 40, LI-COR Inc., Lincoln, NE, USA) was used in Exp. II.

First measurements were done $2-3 \mathrm{~d}$ before the $\mathrm{O}_{3}$ fumigation. The youngest, fully developed leaf of each plant was chosen for all photosynthetic measurements. $\mathrm{CO}_{2}$ response curves $\left(P_{\mathrm{N}}-C_{\mathrm{i}}\right)$ were calculated from the selected leaves using different $\mathrm{CO}_{2}$ concentrations and the maximum light intensity $\left(1,400 \mu \mathrm{mol} \mathrm{m} \mathrm{m}^{-2} \mathrm{~s}^{-1}\right)$. The sequence of $\mathrm{CO}_{2}$ concentrations started from 400 $\mu \mathrm{mol}\left(\mathrm{CO}_{2}\right) \mathrm{mol}^{-1}$ and decreased gradually to $50 \mu \mathrm{mol}$ $\mathrm{mol}^{-1}$. Then, the value increased again from $400 \mu \mathrm{mol}$ $\mathrm{mol}^{-1}$ to the highest value of $1,200 \mu \mathrm{mol} \mathrm{mol} \mathrm{m}^{-1}$. The sequence for the light response curve started from 1,800 $\mu \mathrm{mol}$ (photon) $\mathrm{m}^{-2} \mathrm{~s}^{-1}$ and decreased gradually to zero, with a 15 step decrease, under the controlled $\mathrm{CO}_{2}$ concentration $\left(400 \mu \mathrm{mol} \mathrm{mol}^{-1}\right) \cdot P_{\mathrm{N}}-\mathrm{C}_{\mathrm{i}}$ curves were measured at $\mathrm{t}_{\mathrm{b}}, \mathrm{t}_{20 \mathrm{~m}}$, and $t_{3 w}$. Light-response curves were measured at $t_{b}, t_{20 h}$, and $t_{3 \mathrm{w}}$ in both experiments. In Exp. II, Chl fluorescence light curves and fluorescence $\mathrm{CO}_{2}$ response curves were additionally measured on the light-adapted leaves, and Chl fluorescence parameters were calculated.

Stomata aperture measurement: To determine the response of stomata to $\mathrm{O}_{3}$, epidermis printings were taken using clear nail polish, clear tape and a glass slide within 20 min after ending the $\mathrm{O}_{3}$ exposure. The clear nail polish was applied to the abaxial surface of the leaf and left for a few minutes to dry completely. Then, the clear tape was put on the surface of the stained area, pressed firmly and the tape was removed carefully. The epidermal prints were examined under the microscope and the images of stomata were recorded. The images were analyzed using the $J$ program (National Institute of Health, Bethesda, MD, USA) to determine the length and width of the stomata aperture. The area of the stomata aperture was calculated assuming an elliptical-like shape as $[A=\pi \times L \times W / 2]$, where $\mathrm{W}$ and $\mathrm{L}$ are the length and width of the stomata pore. The values of the stomata aperture were expressed in relation to the control.

$\boldsymbol{P}_{\mathrm{N}}-\boldsymbol{C}_{\mathrm{i}}$ curves were fitted using an $A-C_{i}$ curve-fitting utility, version 1.1 (Sharkey et al. 2007). In this model, the maximum velocity of Rubisco for carboxylation $\left(\mathrm{V}_{\mathrm{cmax}}\right)$ was estimated at low $\mathrm{CO}_{2}$ concentrations $(\sim 200 \mathrm{ppm})$ and the maximum rate of carboxylation limited by the electron transport rate for RuBP generation $\left(\mathrm{J}_{\max }\right)$ was estimated at the $\mathrm{CO}_{2}$ concentration which was higher than $300 \mathrm{ppm}$. Between 200 and $300 \mathrm{ppm}$, there is a transition from one limitation to the other one and these points were normally excluded. The triose phosphate use (TPU) limitation was calculated when the photosynthesis became stable or declined with increasing $\mathrm{CO}_{2}$ concentrations.

Light-response curve: The photosynthetic response of an individual leaf to the incident solar radiation can be described by the photosynthetic response-to-irradiance curve (Thornley 1998). The net photosynthetic rate of a leaf $\left(P_{\mathrm{N}}\right)$ was described as:

$$
P_{\mathrm{N}}=\frac{\alpha \text { PPFD }+P_{\text {max }}-\sqrt{\left\{\left(\alpha \text { PPFD }+P_{\text {max }}\right)^{2}-4 \Theta \alpha \text { PPFD } P_{\text {max }}\right\}}}{2 \Theta}-R_{\mathrm{D}}
$$

where the photosynthetic photon flux density (PPFD) is the PPFD absorbed by the leaf, $\alpha$ is the initial slope of the light curve at low PPFD, $P_{\max }$ is the light-saturated value for photosynthesis, $\Theta$ is the convexity of the light curve, and $R_{\mathrm{D}}$ is the dark respiration rate.

Chl fluorescence parameters: Chl fluorescence measurements were recorded from the fluorescence light curve and fluorescence $\mathrm{CO}_{2}$ response curve of the light-adapted leaves. The values of minimal fluorescence $\left(\mathrm{F}_{0}\right)$ and maximal fluorescence $\left(\mathrm{F}_{\mathrm{m}}\right)$ from the dark-adapted leaves were determined after $30 \mathrm{~min}$ dark period. Exposure of each dark-adapted leaf to the weak, modulated measuring beam [PPFD of $c a$. $0.1 \mu \mathrm{mol} \mathrm{m} \mathrm{m}^{-2} \mathrm{~s}^{-1}$ ] resulted in the minimal fluorescence $\left(\mathrm{F}_{0}\right)$. The short actinic pulse of high PPFD (less than $1 \mathrm{~s}$ at several thousands $\mu \mathrm{mol} \mathrm{m} \mathrm{m}^{-2} \mathrm{~s}^{-1}$ ) to the dark-adapted leaf gave the maximal fluorescence $\left(\mathrm{F}_{\mathrm{m}}\right)$. Calculations for fluorescence parameters were based on the LI-6400/LI-6400XT Version 6.1 software program (LI6400/LI-6400XT 2008).

When the leaf was completely dark-adapted, the optimal quantum efficiency of PSII photochemistry $\left(\mathrm{F}_{\mathrm{v}} / \mathrm{F}_{\mathrm{m}}\right)$ was calculated as:

$$
p_{\text {dark }}=\frac{\mathrm{F}_{\mathrm{m}}-\mathrm{F}_{0}}{\mathrm{~F}_{\mathrm{m}}}=\frac{\mathrm{F}_{\mathrm{v}}}{\mathrm{F}_{\mathrm{m}}}
$$

where $F_{0}$ is known as the minimal fluorescence, $F_{m}$ is the maximal fluorescence, and $p_{\text {dark }}$ is the fraction of absorbed photons that are used for photochemistry in the darkadapted leaf.

If the leaf was completely adapted to light, the efficiency of PSII photochemistry was calculated as:

$$
\Phi_{\text {PSII }}=\frac{\left(\mathrm{F}_{\mathrm{m}}{ }^{\prime}-\mathrm{F}_{\mathrm{s}}\right)}{\mathrm{F}_{\mathrm{m}}{ }^{\prime}}
$$

where $\Phi_{\text {PSII }}$ is the effective quantum yield of PSII photochemistry, $F_{\mathrm{m}}{ }^{\prime}$ is the maximum $\mathrm{Chl}$ fluorescence yield under the light conditions and $F_{s}$ is the steady state fluorescence prior to the flash.

The effective quantum yield of PSII photochemistry was also determined in terms of the efficiency of the energy harvesting by oxidized (open) PSII reaction centers in the light, also referred as the maximal quantum efficiency of PSII and it was calculated as:

$$
\frac{\mathrm{F}_{\mathrm{v}}^{\prime}}{\mathrm{F}_{\mathrm{m}}^{\prime}}=\frac{\mathrm{F}_{\mathrm{m}}^{\prime}-\mathrm{F}_{0}^{\prime}}{\mathrm{F}_{\mathrm{m}}^{\prime}}
$$


The electron transport rate (ETR) was determined as:

$$
\mathrm{ETR}=\Phi_{\mathrm{PSII}} \times \mathrm{I} \times 0.5 \times \alpha_{\mathrm{leaf}}
$$

where $\mathrm{I}$ is the incident photon flux density $\left[\mu \mathrm{mol} \mathrm{m} \mathrm{m}^{-2} \mathrm{~s}^{-1}\right]$, 0.5 is the factor that accounts for the partitioning of energy between PSII and PSI, and $\alpha_{\text {leaf }}$ is the leaf absorbance. A value of 0.84 was used for $\alpha_{\text {leaf }}$.

The quantum yield of the carboxylation rate $\left(\Phi_{\mathrm{CO}_{2}}\right)$ was calculated as:

$$
\Phi_{\mathrm{CO}_{2}}=\frac{P_{\mathrm{N}}-P_{\mathrm{Ndark}}}{\mathrm{I} \times \alpha_{\text {leaf }}}
$$

where $P_{\mathrm{N}}$ is the assimilation rate and $P_{\text {Ndark }}$ is the dark assimilation rate $\left[\mu \mathrm{mol} \mathrm{m} \mathrm{m}^{-2} \mathrm{~s}^{-1}\right]$.

The photochemical quenching coefficient $\left(q_{p}\right)$ was computed from:

$$
\mathrm{q}_{\mathrm{P}}=\frac{\mathrm{F}_{\mathrm{m}}^{\prime}-\mathrm{F}_{\mathrm{s}}}{\mathrm{F}_{\mathrm{m}}^{\prime}-\mathrm{F}_{0}^{\prime}}
$$

where $F_{\mathrm{s}}$ is the steady state fluorescence and $F_{0}{ }^{\prime}$ is the

\section{Results}

Impacts on stomatal conductance $\left(g_{s}\right)$ and stomata aperture: Ozone reduced $g_{\mathrm{s}}$ regardless of the plant age. Before the $\mathrm{O}_{3}$ exposure, the PL30 had higher $g_{\mathrm{s}}$ than the PL51. Twenty minutes after the end of the treatment, $g_{\mathrm{s}}$ was reduced by $85 \%$, from 1.19 to $0.21 \mathrm{~mol}\left(\mathrm{H}_{2} \mathrm{O}\right) \mathrm{m}^{-2} \mathrm{~s}^{-1}$, in the PL30 and by $32 \%$, from 0.46 to $0.28 \mathrm{~mol}\left(\mathrm{H}_{2} \mathrm{O}\right)$ $\mathrm{m}^{-2} \mathrm{~s}^{-1}$, in the PL51 at $\mathrm{O}_{500}$. The $g_{\mathrm{s}}$ reduction was higher as the $\mathrm{O}_{3}$ concentrations increased (Fig. $1 B$ ). Stomata openness was also reduced by $\mathrm{O}_{3}$. The relative value of the stomata pore area (ozone-treated plants compared with the control) decreased from $99 \%$ to $71 \%$ as the $\mathrm{O}_{3}$ concentration increased from $\mathrm{O}_{200}$ to $\mathrm{O}_{500}($ Fig. $1 A$ ).

Response of photosynthesis: The negative response of photosynthesis to ozone stress was observed. Twenty minutes after the end of the $\mathrm{O}_{3}$ exposure, $\mathrm{V}_{\mathrm{cmax}}$ of the PL30 was reduced from $89 \mu \mathrm{mol} \mathrm{m} \mathrm{m}^{-2} \mathrm{~s}^{-1}$ (control) to $37 \mu \mathrm{mol}$ $\mathrm{m}^{-2} \mathrm{~s}^{-1}\left(\mathrm{O}_{500}\right)$; this represented the $58 \%$ reduction relative to the control (Fig. $2 A$ ). Similarly, $\mathrm{J}_{\max }$ was depressed by $70 \%$ (Fig. $2 B$ ) and TPU by $68 \%$ relative to the control (Fig. 2C). In the PL51, the maximum decline was observed at $\mathrm{O}_{500}$ (reduction of $42 \% \mathrm{~V}_{\mathrm{cmax}}, 33 \% \mathrm{~J}_{\max }$, and $35 \% \mathrm{TPU}$ relative to the control), followed by $\mathrm{O}_{350}$ and $\mathrm{O}_{200}$, respectively (Fig. 2D,E,F).

At $t_{20 h}$, the similar and consistent reduction was observed in both experiments. For $\mathrm{O}_{500}$, and in the PL30 (Exp. I), $P_{\max }$ was reduced by $78 \%$, $\Theta$ by $4 \%$, and $\alpha$ by 68 $\%$. In the PL51 (Exp. II), $P_{\max }$ was depressed by $33 \%$, $\Theta$ by $7 \%$, and $\alpha$ by $15 \%$ (Table 1 ). The reduction intensified as the $\mathrm{O}_{3}$ concentration rose during both measurements minimal fluorescence of the light-adapted leaf that was momentarily darkened. The minimal fluorescence $\left(\mathrm{F}_{0}{ }^{\prime}\right)$ was determined using far-red light to excite PSI and to force electrons to drain from PSII. The LI-COR 6400 - 40 provided a 'dark pulse' routine to determine $\mathrm{F}_{0}$ '.

Curve fitting: The exponential decay function with two parameters was utilized to fit the curve of the $\Phi_{\text {PSII }}$ (Ritchie 2008, Iacono and Sommer 2000), the $\Phi_{\mathrm{CO}_{2}}, \mathrm{~F}_{\mathrm{v}}{ }^{\prime} / \mathrm{F}_{\mathrm{m}}{ }^{\prime}$, and $\mathrm{q}_{\mathrm{P}}$ with varying PPFD. To fit the growth curve for ETR vs. PPFD, the nonrectangular hyperbola was used (Thornley 1998, Iacono and Sommer 2000). The slope of the curve and the maximum value of each function were compared between the treatments and controls.

Statistical analysis: Data was analyzed using $S A S$ version 9.2 (SAS Institute Cary 2007). To determine mean values of two groups (before and after the $\mathrm{O}_{3}$ exposure or exposed and nonexposed $\mathrm{O}_{3}$ ), a $t$-test comparison was used. Differences in $\mathrm{O}_{3}$ concentrations were assessed using oneway comparison by $A N O V A$ followed by LSD test at the significant level of $5 \%$.

$\left(\mathrm{t}_{20 \mathrm{~m}}\right.$ and $\left.\mathrm{t}_{20 \mathrm{~h}}\right)$ (Fig. 2, Table 1). Comparing both growth stages, the PL30 showed the higher reduction than that of the PL51 under the same concentration $\mathrm{O}_{500}$ (Fig. 2, Table 1).

After $t_{3 \mathrm{w}}$, no significant differences of the parameters (i.e. light- and $\mathrm{CO}_{2}$-response curves) could be observed between the ozone-exposed and the control plants in both growth stages (Fig. 2, Table 1). It suggested that leaf photosynthesis was not permanently affected in tomato by the acute ozone stress regardless of the growth stage.

Response of Chl fluorescence characteristics: The parameters of $\mathrm{Chl}$ fluorescence were measured only during Exp. II (PL51). The results indicated that $\mathrm{O}_{3}$ reduced the value of the $\mathrm{F}_{\mathrm{v}} / \mathrm{F}_{\mathrm{m}}$ ratio just after the $\mathrm{O}_{3}$ treatment. Significant differences were observed at $\mathrm{O}_{500}(0.73)$ and $\mathrm{O}_{350}(0.77)$ in comparison with the control plants. The $\mathrm{O}_{3}$ concentration $\mathrm{O}_{200}$ did not show any significant impact on $\mathrm{F}_{\mathrm{v}} / \mathrm{F}_{\mathrm{m}}$ (Table 2). The changes of the Chl fluorescence parameters in response to the increasing light intensity are described in Fig. 3. The ETR gradually rose as the light intensity increased. Other parameters $\left(\Phi_{\mathrm{PSII}}, \Phi_{\mathrm{CO} 2}, \mathrm{q}_{\mathrm{P}}\right.$, and $\left.\mathrm{F}_{\mathrm{v}}{ }^{\prime} / \mathrm{F}_{\mathrm{m}}{ }^{\prime}\right)$ showed the exponential decrease with the increasing light intensity. To compare the parameters of the curves among the treatments, the curves were fitted using different parameters. For all fitted curves, the initial slope as well as the maximum value of the curve from the ozone-treated plants was reduced under the ozone stress The greatest rate of the decrease was observed for $\mathrm{O}_{500}$, followed by $\mathrm{O}_{350}$ and $\mathrm{O}_{200}$ in all parameters measured 


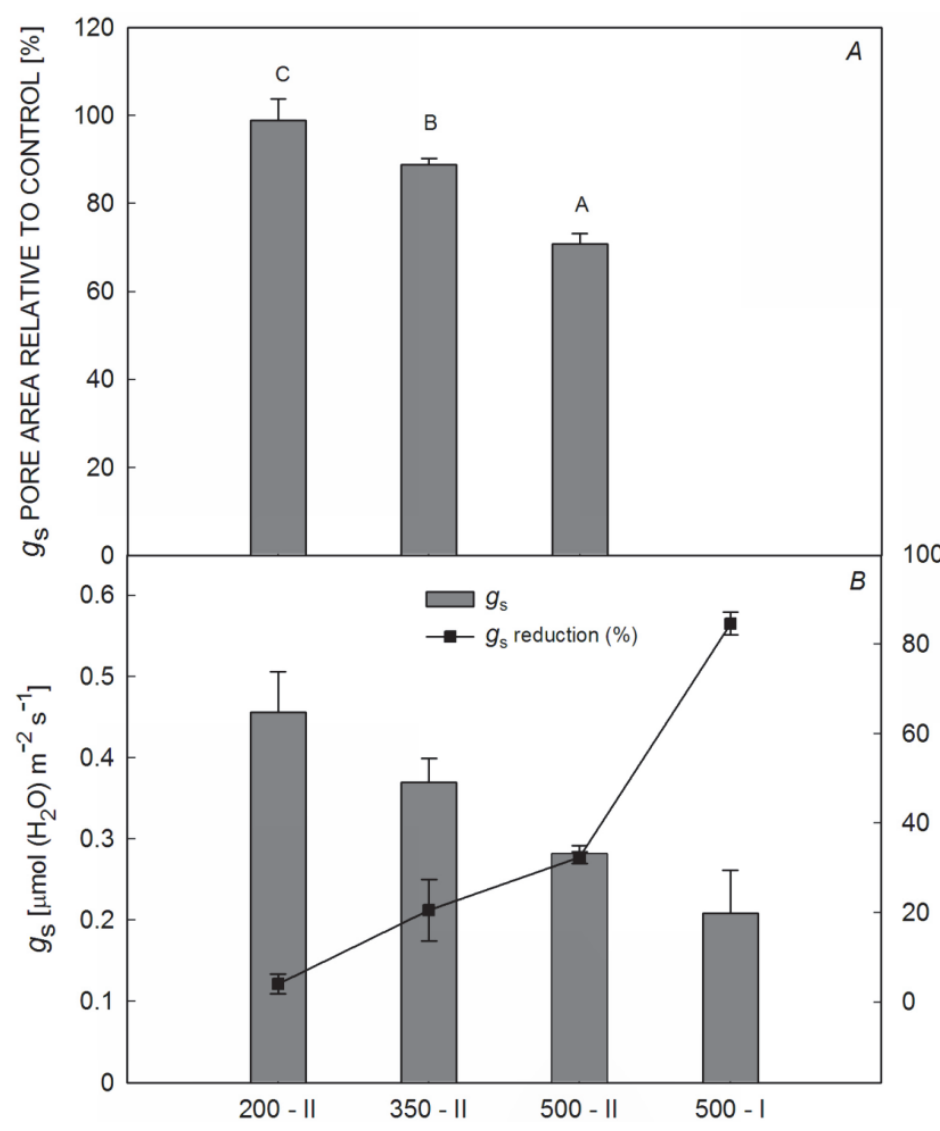

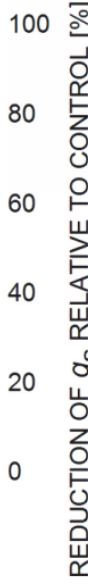

Fig. $1 \mathrm{~A}$ : Comparison of stomata pore area (stomatal openness) relative to control after ozone $\left(\mathrm{O}_{3}\right)$ treatment, $B$ : Comparison of stomatal conductance $\left(g_{\mathrm{s}}\right)$ and reduction of $g_{\mathrm{s}}$ relative to control after $\mathrm{O}_{3}$ exposure. Measurements for stomata pore area were taken within 20 min after the end of $\mathrm{O}_{3}$ exposure. Mean \pm SE $(n=70 \sim 90)$. I and II - ozone experiments I and II.
(Fig. 3, Table 3). Moreover, these parameters (slope and the maximum asymptote of the curve) were significantly different among the treatments.

To determine the characteristics of the fluorescence parameters among the different $\mathrm{O}_{3}$ concentrations and their recovery potential, the parameters were measured 4 times in different evaluation periods. The significant differences

\section{Discussion}

The experiments were carried out to characterize the ozone impacts on photosynthesis and $\mathrm{Chl}$ fluorescence parameters at two growth stages of tomato. The results demonstrated that the photosynthetic apparatus of tomato was impaired by the $\mathrm{O}_{3}$ exposure. The damage varied with regard to the $\mathrm{O}_{3}$ concentrations and plant age. The higher impact was observed as the $\mathrm{O}_{3}$ concentrations increased. Moreover, the younger plants suffered more than the older ones.

$P_{\mathrm{N}}-C_{\mathrm{i}}$ curve parameters measured at $\mathrm{t}_{20 \mathrm{~m}}$ indicated that $\mathrm{O}_{3}$ induced the inhibition of the biochemical kinetic variables ( $\mathrm{V}_{\mathrm{cmax}}, \mathrm{J}_{\max }$, TPU) irrespective of the plant age. The significant decline was detected just after the $\mathrm{O}_{500}$ exposure and above (Fig. 2). The $\mathrm{O}_{3}$ concentration $\mathrm{O}_{200}$ did not show any significant impact. Ozone promotes proteolysis, accelerates the reduction of Rubisco (Dann and Pell 1989) and induces the ethylene production that were observed just after the $\mathrm{O}_{3}$ exposure (at $\mathrm{t}_{20 \mathrm{~m}}$ and $\mathrm{t}_{20 \mathrm{~h}}$ ). No significant difference of reduction percentage was observed between $\mathrm{t}_{20 \mathrm{~m}}$ and $\mathrm{t}_{20 \mathrm{~h}}$. Among the treatments, $\mathrm{O}_{350}$ and $\mathrm{O}_{500}$ showed significantly lower values (ETR, $\Phi_{\text {PSII }}$ $\Phi_{\mathrm{CO} 2}$, and $\mathrm{q}_{\mathrm{P}}$ ) than the control. Measurements done 3 weeks later suggested a recovery process from $\mathrm{O}_{3}$ injury in tomato (Fig. 4).

reduces the Rubisco protein content (Glick et al. 1995). Since Rubisco is the crucial enzyme of the Calvin cycle, the enzyme degradation could lower the capacity of Rubisco to consume RuBP (Sage and Reid 1994). Based on the current results, $\mathrm{V}_{\mathrm{cmax}}$ was reduced as the $\mathrm{O}_{3}$ concentration rose (Fig. 2). In addition, the younger plants were more affected at the same $\mathrm{O}_{3}$ concentration indicating that Rubisco degradation was higher under stress during the earlier stage of plant development.

The same trend was also observed in ETR for RuBP generation $\left(\mathrm{J}_{\max }\right)$. The ETR reduction in dependence on the increasing $\mathrm{O}_{3}$ concentration could be linked to $\alpha$. Under ozone stress, the ability of the plants to produce oxygen decreased and it lowered the quantum yield. In both experiments, $\alpha$ was significantly reduced at $\mathrm{O}_{500}$ with the greater reduction in the younger plants $(68 \%)$ than in the older ones $(15 \%)$ (Table 1$)$. The reduced $\alpha$ lowers 


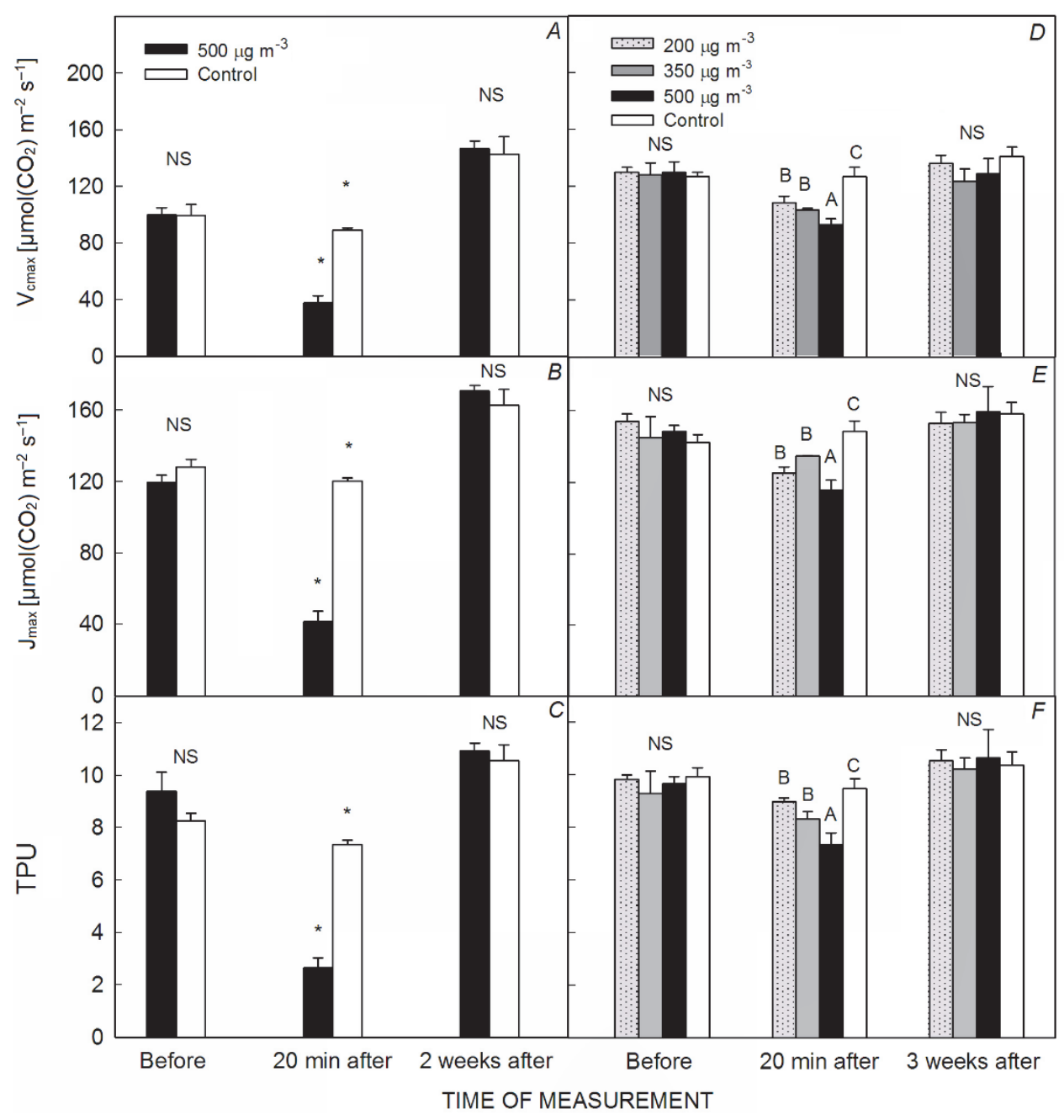

Fig. 2. Comparison of $P_{\mathrm{N}}-C_{\mathrm{i}}$ curve parameters between two different growth stages. $A-C$ : 30 -day-old plants (PL30) and $D-F$ : 51day-old plants (PL51). A,D: $\mathrm{V}_{\mathrm{cmax}}$ - maximum apparent rate of Rubisco carboxylation, $B, E: \mathrm{J}_{\max }$ - maximum electron transport rate for RuBP regeneration, and $C, F$ : TPU - triose phosphate use. Mean \pm SE $(n=5)$. Open symbols indicate control and closed symbols indicate $\mathrm{O}_{3}$-treated plants.

Table 1. Comparison of light-response curve parameters for 30- (PL30) and 51-d-old plants (PL51) at different ozone concentrations. $P_{\max }$ - light-saturated photosynthetic rate, $\alpha$ - initial slope of the light curve at low PPFD, $\Theta$ - convexity of the light curve. Parameters were derived from light-response curves measured at $20 \mathrm{~h}\left(\mathrm{t}_{20 \mathrm{~h}}\right)$ and 2-3 weeks $\left(\mathrm{t}_{3 \mathrm{w}}\right)$ after the end of ozone exposure. Parameters were compared for each treatment and each control. Mean $(n=5)$. The value inside the parentheses is the reduction percentage of ozonetreated plants relative to control. * in the same column indicates the significant level between the treatment and control for each ozone concentration. $*$ - significant at $p<0.05, * *$ - significant at $p<0.01$.

\begin{tabular}{|c|c|c|c|c|c|c|c|}
\hline Plant & Ozone $\left[\mu \mathrm{g} \mathrm{m}^{-3}\right]$ & $\begin{array}{l}\alpha \\
\mathrm{t}_{20 \mathrm{~h}}\end{array}$ & $\Theta$ & $P_{\max }\left[\mu \mathrm{mol}\left(\mathrm{CO}_{2}\right) \mathrm{m}^{-2} \mathrm{~s}^{-1}\right]$ & $\begin{array}{l}\alpha \\
t_{3 w}\end{array}$ & $\Theta$ & $P_{\max }\left[\mu \mathrm{mol}\left(\mathrm{CO}_{2}\right) \mathrm{m}^{-2} \mathrm{~s}^{-1}\right]$ \\
\hline \multirow[t]{2}{*}{ PL30 } & 0 & $0.06^{* *}$ & 0.73 & $32.10^{* *}$ & 0.06 & 0.75 & 30.44 \\
\hline & 500 & $0.02(-68 \%)^{* *}$ & $0.70(-4 \%)$ & $5.15(-78 \%)^{* *}$ & 0.06 & 0.73 & 32.10 \\
\hline \multirow[t]{6}{*}{ PL51 } & 0 & 0.06 & 0.79 & 26.05 & 0.07 & 0.87 & 23.74 \\
\hline & 200 & $0.06(-4 \%)$ & $0.71(-5 \%)$ & $23.30(-9 \%)$ & 0.06 & 0.77 & 20.58 \\
\hline & 0 & 0.06 & 0.81 & 27.80 & 0.06 & 0.79 & 22.60 \\
\hline & 350 & $0.06(-5 \%)$ & $0.77(-5 \%)$ & $24.02(-10 \%)$ & 0.06 & 0.74 & 19.10 \\
\hline & 0 & $0.06^{*}$ & 0.86 & $19.87^{*}$ & 0.07 & 0.76 & 24.57 \\
\hline & 500 & $0.05(-15 \%)^{*}$ & $0.83(-7 \%)$ & $13.29(-33 \%)^{*}$ & 0.06 & 0.82 & 23.51 \\
\hline
\end{tabular}


Table 2. Comparison of maximum quantum efficiency of PSII photochemistry $\left(\mathrm{F}_{\mathrm{v}} / \mathrm{F}_{\mathrm{m}}\right)$ from the dark-adapted leaf between the treatments and controls. Mean $\pm \mathrm{SE}(n=5)$. Comparisons were made for each ozone concentration between the treatment and control (the same row) and among different ozone concentrations (the same column). ${ }^{*}$ in the same row indicates the significant level between the treatment and control and a capital letter in the same column indicates a comparison among the ozone concentrations. The same letters in the same column assign not significantly different values. ns - not significant, ${ }^{*}$ - significant at $p<0.05,{ }^{* *}-$ significant at $p<0.01$.

\begin{tabular}{lllllll}
\hline Ozone $\left[\mu \mathrm{g} \mathrm{m}^{-3}\right]$ & Before treatment & Control & Just after treatment & Control & $\begin{array}{l}3 \text { weeks after } \\
\text { treatment }\end{array}$ & Control \\
\hline 200 & $0.80 \pm 0.004^{\mathrm{ns}}$ & $0.79 \pm 0.013^{\mathrm{ns}}$ & $0.78 \pm 0.005^{\mathrm{ns} B}$ & $0.80 \pm 0.004^{\mathrm{ns}}$ & $0.79 \pm 0.004^{\mathrm{ns}}$ & $0.80 \pm 0.004^{\mathrm{ns}}$ \\
350 & $0.81 \pm 0.006^{\mathrm{ns}}$ & $0.79 \pm 0.010^{\mathrm{ns}}$ & $0.77 \pm 0.008^{*} B$ & $0.79 \pm 0.007^{*}$ & $0.81 \pm 0.006^{\mathrm{ns}}$ & $0.81 \pm 0.010^{\mathrm{ns}}$ \\
500 & $0.79 \pm 0.004^{\mathrm{ns}}$ & $0.79 \pm 0.006^{\mathrm{ns}}$ & $0.73 \pm 0.002^{* *} A$ & $0.80 \pm 0.002^{* *}$ & $0.81 \pm 0.008^{\mathrm{ns}}$ & $0.82 \pm 0.004^{\mathrm{ns}}$ \\
\hline
\end{tabular}

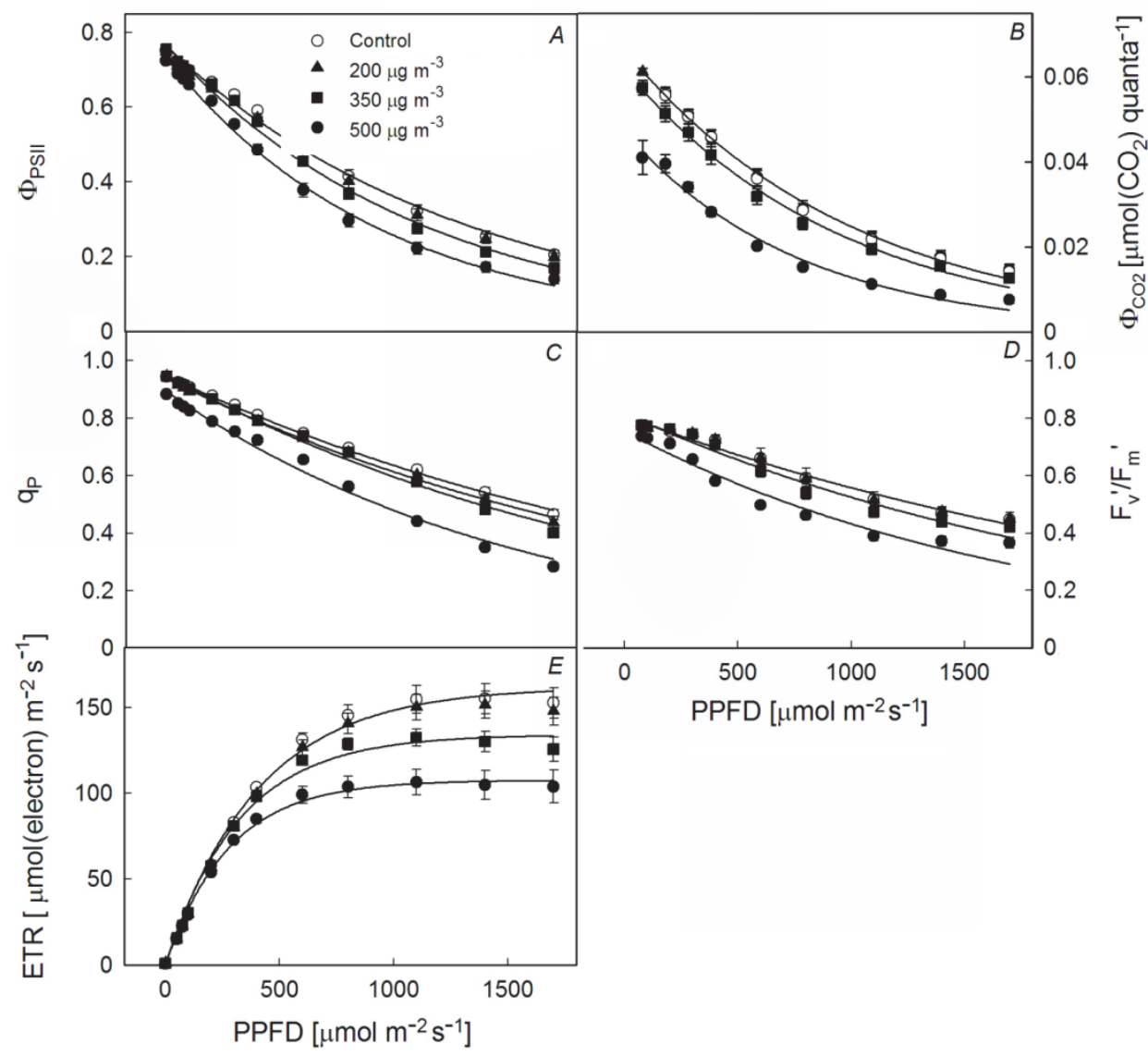

Fig. 3. Comparison of fluorescence parameters between the $\mathrm{O}_{3}$-treated plants and control to varying PPFD. A: Quantum yield of PSII (ФPSII), $B$ : Quantum yield of $\mathrm{CO}_{2}$ assimilation $\left(\Phi_{\mathrm{CO} 2}\right), C$ : Photochemical quenching (qP), $D$ : Photosystem II maximum efficiency $\left(\mathrm{F}_{\mathrm{v}}{ }^{\prime} / \mathrm{F}_{\mathrm{m}}\right)$, and $E$ : Electron transport rate (ETR). Measurements were taken $20 \mathrm{~h}$ after the end of fumigation. ( $(\circ)$ Control, ( $\left.\boldsymbol{\Delta}\right) 200 \mu \mathrm{g} \mathrm{m}{ }^{-3}$, (•) $350 \mu \mathrm{g} \mathrm{m}^{-3},(\bullet) 500 \mu \mathrm{g} \mathrm{m}^{-3}$. Open symbols indicate control and closed symbols indicate $\mathrm{O}_{3}$-treated plants. Mean $\pm \mathrm{SE}(\mathrm{n}=5)$. Lines were fitted curve using estimated parameters.

ETR and reduces the strength of ATP production (Moore et al. 1995). Moreover in our experiments, the decline in TPU (Fig. 2C,F) revealed the lowered $\alpha$ and the reduced carboxylation efficiency under ozone stress. Thus, the capacity of starch and sucrose synthesis to regenerate inorganic phosphate $\left(\mathrm{P}_{\mathrm{i}}\right)$ from triose phosphate was limited under ozone stress. Sage and Reid (1994) reported that starch and sucrose synthesis can influence the rate of RuBP regeneration by failing to metabolize triose phosphates as fast as they are produced. As a result, the level of $\mathrm{P}_{\mathrm{i}}$ becomes progressively lower under the high $\mathrm{O}_{3}$ concentration. 
Table 3. Chlorophyll fluorescence parameters between ozone-treated and nontreated plants to varying light intensity PPFD. ETR electron transport rate, $\Phi_{\mathrm{PSII}}$ - effective quantum yield of photosystem II photochemistry, $\Phi_{\mathrm{CO} 2}$ - quantum yield of carboxylation rate, $\mathrm{qp}-$ photochemical quenching coefficient, $\mathrm{F}_{\mathrm{v}}{ }^{\prime} / \mathrm{F}_{\mathrm{m}}{ }^{\prime}-$ maximal quantum efficiency of PSII. Parameters were derived from nonlinear curve fitting. Equation parameter 'a' means maximum asymptote and ' $\mathrm{b}$ ' means the slope of the fitted curve. Mean $(n=5)$. Measurements were taken $20 \mathrm{~h}$ after the end of ozone exposure.

\begin{tabular}{|c|c|c|c|c|c|}
\hline Parameter & Equation & Ozone $\left[\mu \mathrm{g} \mathrm{m}^{-3}\right.$ ] & $\begin{array}{l}\text { Parameter } \\
\text { a }\end{array}$ & $\begin{array}{l}\text { m equation } \\
\mathrm{b}\end{array}$ & $r^{2}$ \\
\hline ETR & Refer to Eq. 1 & $\begin{array}{l}0 \\
200 \\
350 \\
500\end{array}$ & $\begin{array}{l}161.750^{\mathrm{d}} \\
152.974^{\mathrm{c}} \\
139.480^{\mathrm{b}} \\
106.600^{\mathrm{a}}\end{array}$ & $\begin{array}{l}0.29^{\mathrm{c}} \\
0.28^{\mathrm{b}} \\
0.28^{\mathrm{b}} \\
0.26^{\mathrm{a}}\end{array}$ & $\begin{array}{l}0.99 \\
0.99 \\
0.99 \\
0.99\end{array}$ \\
\hline$\Phi_{\text {PSII }}$ & $Y=a e^{-b x}$ & $\begin{array}{l}0 \\
200 \\
350 \\
500\end{array}$ & $\begin{array}{l}0.760^{\mathrm{ab}} \\
0.750^{\mathrm{ab}} \\
0.770^{\mathrm{b}} \\
0.730^{\mathrm{a}}\end{array}$ & $\begin{array}{l}0.00070^{\mathrm{a}} \\
0.00070^{\mathrm{a}} \\
0.00080^{\mathrm{b}} \\
0.00110^{\mathrm{c}}\end{array}$ & $\begin{array}{l}0.99 \\
0.99 \\
0.99 \\
0.99\end{array}$ \\
\hline$\Phi_{\mathrm{CO}_{2}}$ & $Y=a e^{-b x}$ & $\begin{array}{l}0 \\
200 \\
350 \\
500\end{array}$ & $\begin{array}{l}0.066^{b} \\
0.064^{b} \\
0.069^{b} \\
0.053^{a}\end{array}$ & $\begin{array}{l}0.00096^{\mathrm{a}} \\
0.00107^{\mathrm{c}} \\
0.00100^{\mathrm{b}} \\
0.00142^{\mathrm{d}}\end{array}$ & $\begin{array}{l}0.99 \\
0.99 \\
0.99 \\
0.99\end{array}$ \\
\hline qP & $Y=a e^{-b x}$ & $\begin{array}{l}0 \\
200 \\
350 \\
500\end{array}$ & $\begin{array}{l}0.950^{\text {ns }} \\
0.950^{\text {ns }} \\
0.940^{\text {ns }} \\
0.850^{\text {ns }}\end{array}$ & $\begin{array}{l}0.00039^{\mathrm{a}} \\
0.00045^{\mathrm{a}} \\
0.00045^{\mathrm{a}} \\
0.00077^{\mathrm{b}}\end{array}$ & $\begin{array}{l}0.99 \\
0.99 \\
0.99 \\
0.99\end{array}$ \\
\hline $\mathrm{F}_{\mathrm{v}}{ }^{\prime} / \mathrm{F}_{\mathrm{m}}{ }^{\prime}$ & $\mathrm{Y}=\mathrm{a} \mathrm{e}^{-\mathrm{bx}}$ & $\begin{array}{l}0 \\
200 \\
350 \\
500\end{array}$ & $\begin{array}{l}0.807^{b} \\
0.804^{b} \\
0.811^{b} \\
0.763^{a}\end{array}$ & $\begin{array}{l}0.00035^{\mathrm{a}} \\
0.00038^{\mathrm{a}} \\
0.00045^{\mathrm{b}} \\
0.00057^{\mathrm{c}}\end{array}$ & $\begin{array}{l}0.98 \\
0.98 \\
0.97 \\
0.92\end{array}$ \\
\hline
\end{tabular}

If $\mathrm{P}_{\mathrm{i}}$ decline to the critical levels, photophosphorylation can be inhibited, reducing ATP synthesis and in turn RuBP regeneration. Consequently, photosynthesis declined due to the increasing $\mathrm{O}_{3}$ concentration (Table 1).

The above results indicated that the responses to $\mathrm{O}_{3}$ were stronger as the concentrations increased with a significant reduction at $\mathrm{O}_{350}\left(P_{\mathrm{N}}-C_{\mathrm{i}}\right.$ curve parameters $)$ and $\mathrm{O}_{500}\left(P_{\mathrm{N}}-\mathrm{Ci}\right.$ and light curve parameters). In addition, there was a consistent reduction in the photosynthetic parameters of the younger plants compared with the older ones at $\mathrm{O}_{500}$. It highlighted that younger plants were more susceptible. The variation in the foliar injury between both growth stages supported the above results. The higher foliar injury from $\mathrm{O}_{3}$ have been already reported in PL30 compared with the PL51 (Thwe et al. 2013). This indicated the age-dependent $\mathrm{O}_{3}$ sensitivity in tomato. Kolb et al. (1997) stated that $\mathrm{O}_{3}$ sensitivity depends on the ontogenetic changes of $g_{\mathrm{s}}$ in accordance with the plant age. The $\mathrm{O}_{3}$ uptake could be higher in the plants that have the higher $g_{\mathrm{s}}$ than in those having the lower $g_{\mathrm{s}}$ (Reich 1987, Fredericksen et al. 1996). Although there were large differences in the $g_{\mathrm{s}}$ between both growth stages in our experiments, they could be explained partially by the agerelated differences in $\mathrm{O}_{3}$-susceptibility. The literature shows that $\mathrm{O}_{3}$-sensitivity is related to ontogenetic trends in leaf morphology (Ferdinand et al. 2000) and biochemistry
(Wellburn and Wellburn 1996, Burkey et al. 2000). Ozone sensitivity is associated with leaf characteristics related to the ability of $\mathrm{O}_{3}$ to diffuse into the leaves (high stomata densities) and the ability of $\mathrm{O}_{3}$ to diffuse among the target cells (high percentage of intercellular spaces among palisade parenchyma cells) (Evans et al. 1996, Wieser et al. 2002). In our experiments, the younger plants were at the vegetative stage while the older ones were at the generative stage bearing fruits at the time of the $\mathrm{O}_{3}$ exposure. Pressman et al. (1997) indicated that concentrations of soluble sugars and starch in leaves were promoted with the increasing truss number in tomato, and these increased the sugar content of the leaves which could cause the closure of stomata leading to a reduction in leaf injury (Leipner et al. 2001). Thus, different contents of biochemical compounds and leaf morphological characteristics in accordance with the plant growth stage modify the entry of $\mathrm{O}_{3}$ into the plant cells (Fredericksen et al. 1995). In addition, the strong reduction of $g_{\mathrm{s}}$ and the stomata pore area revealed the direct effect on the stomata, as the $\mathrm{O}_{3}$ concentrations increased. Stomata closure in response to $\mathrm{O}_{3}$ is regarded as a protective mechanism and has been documented by other authors (Hill and Littlefield 1969, Calatayud et al. 2002, 2004, McKee et al. 1995). Even if stomata closure was larger as the $\mathrm{O}_{3}$ concentrations increased, it would not prevent the leaf injury. 


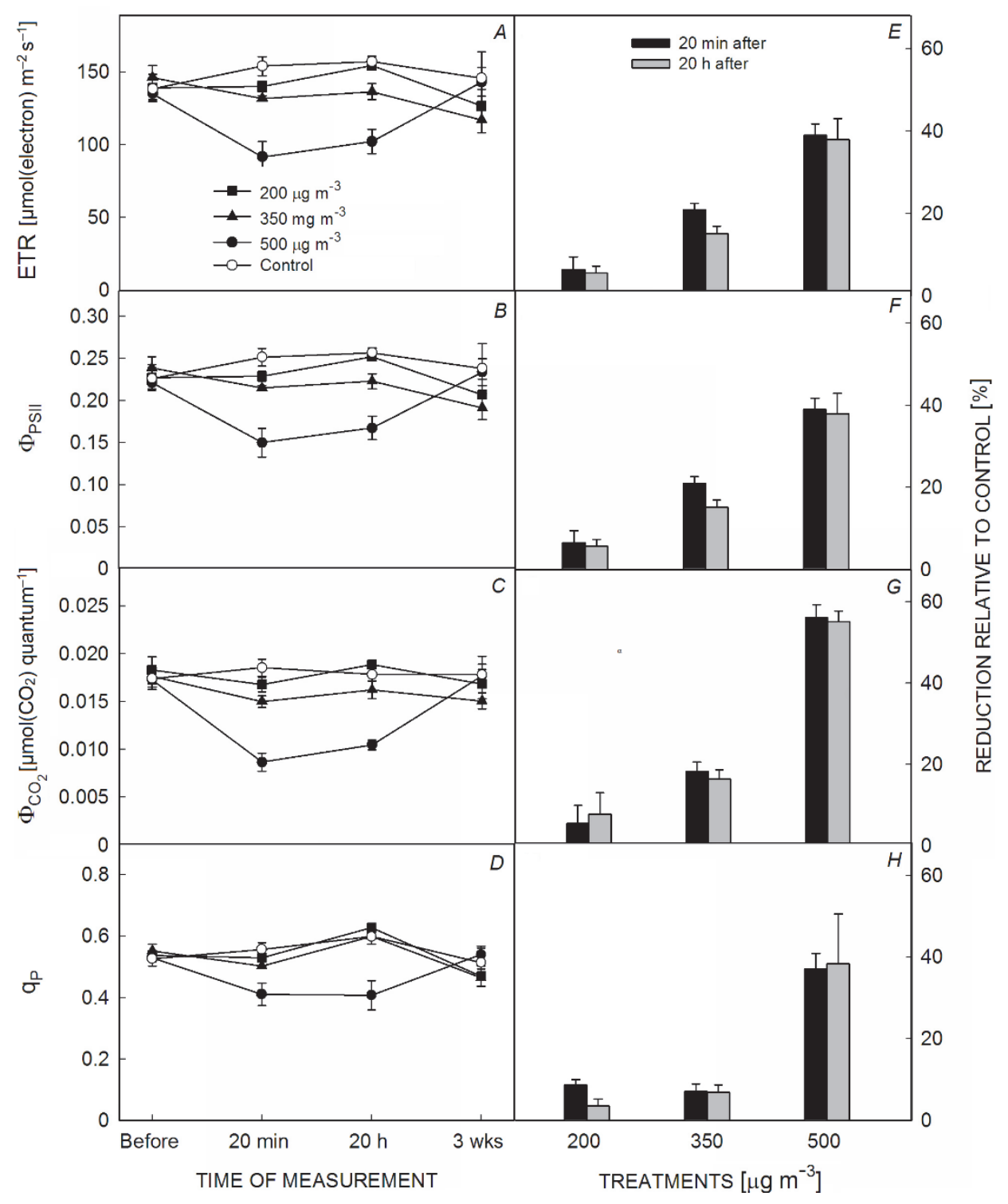

Fig. 4. Comparison of chlorophyll fluorescence parameters and the percentage of a reduction among different $\mathrm{O}_{3}$ concentrations at different evaluation periods, and for $1,400 \mu \mathrm{mol} \mathrm{m}^{-2} \mathrm{~s}^{-1}$ PPFD and $400 \mu \mathrm{mol} \mathrm{mol}^{-1}\left(\mathrm{CO}_{2}\right)$. A,E: Electron transport rate (ETR), $B, F$ : Quantum yield of PSII ( $\left.\Phi_{\mathrm{PSII}}\right), C, G$ : Quantum yield of $\mathrm{CO}_{2}$ assimilation $\left(\Phi_{\mathrm{CO} 2}\right)$, and $D, H$ : Photochemical quenching efficiency (qP). (०)

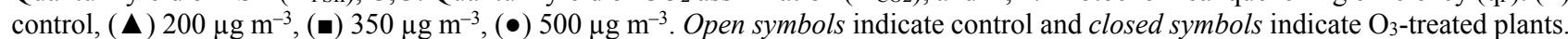
Mean $\pm \mathrm{SE}(n=5)$. Measurements were started before $\mathrm{O}_{3}$ exposure (Before), $20 \mathrm{~min}, 20 \mathrm{~h}$, and 3 weeks after the end of $\mathrm{O}_{3}$ exposure (20 $\mathrm{min}, 20 \mathrm{~h}$, and 3 weeks).

It suggests that $\mathrm{O}_{3}$ had already entered the plant cells before the measurements were recorded because stomata responses were measured $20 \mathrm{~min}$ after the end of the $\mathrm{O}_{3}$ exposure. Stomata closure influences the $\mathrm{CO}_{2}$ uptake; thus the reduction in the $\mathrm{CO}_{2}$ uptake could be partially responsible for the decline of photosynthesis.

Since Chl fluorescence provides information about the light reaction of photosynthesis, it serves as a noninvasive indicator of the status of photosynthetic reaction centers (Calatayud et al. 2006). The results of our Exp. II showed that the ratio of $\mathrm{F}_{\mathrm{v}} / \mathrm{F}_{\mathrm{m}}$ from the dark-adapted leaves decreased more apparently at the highest $\mathrm{O}_{3}$ concentration
$\left(\mathrm{O}_{500}\right)$. It revealed that $\mathrm{O}_{3}$ limits the capability of the plant to use photon energy and thus it alters photosynthetic processes (Calatayud et al. 2006). Our fluorescence parameters $\left(\mathrm{ETR}, \Phi_{\mathrm{PSII}}, \Phi_{\mathrm{CO} 2}\right.$, and $\left.\mathrm{q}_{\mathrm{P}}\right)$ supported these findings. Among the four evaluation periods $\left(t_{b}, t_{20 m}, t_{20 h}\right.$, and $t_{3 w}$,), the ozone-treated plants showed consistently the significant and more obvious depression in both $t_{20 \mathrm{~m}}$ and $\mathrm{t}_{20 \mathrm{~h}}$ at $\mathrm{O}_{500}$. No significant difference between $\mathrm{t}_{20 \mathrm{~m}}$ and $\mathrm{t}_{20 \mathrm{~h}}$ implied that stress still proceeded until $20 \mathrm{~h}$ (Fig. 4). The curves (fluorescence parameters vs. PPFD) were fitted and the fitted parameters were evaluated to determine the stress intensity among the $\mathrm{O}_{3}$ concentrations. The results 
indicated that the initial slope as well as the maximum value (the maximum asymptote) of the fitted curves were significantly different among the treatments with the highest decline or the lowest rate of increase at $\mathrm{O}_{500}$ suggesting the dysfunction of photosystems under $\mathrm{O}_{3}$ stress. Reduced $\Phi_{\text {PSII }}$ revealed that the ability of the leaf to remove electrons from the quinone acceptors of PSII was reduced. The decrease in the rate of NADPH and ATP consumption can result from the decrease in the carboxylation efficiency, in the rate of regeneration of RuBP, and in the supply of $\mathrm{CO}_{2}$ via the stomata to the sites of carboxylation. Such restrictions on PSII electron transport reduce the rate of excitation of the PSII reaction centers and prevent the PSII quinone acceptors becoming highly reduced. With the increasing level of stress, the increase in nonphotochemical quenching can be insufficient to maintain the partial oxidization of the PSII electron acceptors and then photodamage to PSII occurs (Ort and Baker 2002). Calatayud et al. (2004) also stated that the limitation of photosynthesis is correlated with the reduction in the efficiency of energy conversion of PSII, decreasing the rate of noncyclic electron flow and the capacity to reduce the quinone pool. Thus, a decline in photosynthesis and other related parameters at increasing ozone concentrations reflects the occurrence of damaged photosystems.

With regard to the recovery process, photosynthetic depression was not the permanent process and tomato plants had the potential to regain photosynthetic activity after the acute $\mathrm{O}_{3}$ exposure. Since photosynthetic measurements were made on the youngest, fully developed leaf, the interpretation of the photosynthetic recovery process did not represent the whole plant recovery function. The whole plant recovery process is different, it depends on the level of $\mathrm{O}_{3}$ injury in accordance with the

\section{References}

Baker, N.R., Rosenqvist, E.: Applications of chlorophyll fluorescence can improve crop production strategies: an examination of future possibilities. - J. Exp. Bot. 55: 1607-1621, 2004.

Bell, M.L., Peng, R.D., Dominici, F.: The exposure-response curve for ozone and risk of mortality and the adequacy of current ozone regulations. - Environ. Health Persp. 114: 532536, 2006.

Burkey, K.O.,Wei, C., Eason, G. et al.: Antioxidant metabolite levels in ozone-sensitive and tolerant genotypes of snap bean. - Physiol. Plantarum 110: 195-200, 2000.

Calatayud, A., Ramirez, J.W., Iglesias, D.J., Barreno, E.: Effects of ozone on photosynthetic $\mathrm{CO}_{2}$ exchange, chlorophyll a fluorescence and antioxidant systems in lettuce leaves. Physiol. Plantarum 116: 308-316, 2002.

Calatayud, A., Iglesias, D.J., Talón, M., Barreno, E.: Response of spinach leaves (Spinacia oleracea $\mathrm{L}$.) to ozone measured by gas exchange, chlorophyll a fluorescence, antioxidant systems, and lipid peroxidation. - Photosynthetica 42: 23-29, 2004.

Calatayud, A., Iglesias, D.J., Talón, M., Barreno, E.: Effects of plant age and the $\mathrm{O}_{3}$ concentration at the time of stress as it has been described in the previous article (Thwe et al. 2013). Thus, the permanent decrease of photosynthesis linked to the irreversible leaf injury was associated with the temporary depression of photosynthesis linked to $g_{\mathrm{s}}$ and the photosynthetic system. Hence, acquisition of carbohydrates and their next translocation in accordance with the photosynthetic injury should be considered for further plant growth and development.

Conclusion: Tomato is the ozone-sensitive crop. The biochemical kinetic variables $\left(\mathrm{V}_{\mathrm{cmax}}, \mathrm{J}_{\max }, \mathrm{TPU}\right)$ and $\alpha$ were inhibited under ozone stress leading to reduced $P_{\mathrm{N}}$ irrespective of the plant age. The intensity of the $\mathrm{O}_{3}$ injury was stronger as the concentrations increased with a significant difference at $\mathrm{O}_{350}\left(P_{\mathrm{N}}-C_{\mathrm{i}}\right.$ curve parameters $)$ and $\mathrm{O}_{500}\left(P_{\mathrm{N}^{-}} C_{\mathrm{i}}\right.$ and light curve parameters $)$. At $\mathrm{O}_{500}$, the injury was higher in the younger plants than in the older ones revealing that younger plants were more susceptible. The worse photosynthetic injuries of the younger plants (PL30) than in the older ones (PL51) indicated the age-dependent $\mathrm{O}_{3}$ sensitivity. The strong reduction of $g_{\mathrm{s}}$ and the stomata pore area as the $\mathrm{O}_{3}$ concentration highlighted the direct impact of $\mathrm{O}_{3}$ on the stomata. The decline of $\mathrm{F}_{\mathrm{v}} / \mathrm{F}_{\mathrm{m}}$ from the dark-adapted leaf indicated that $\mathrm{O}_{3}$ caused the photoinhibition of PSII activity. Thus, the decline of photosynthesis as the $\mathrm{O}_{3}$ concentrations increased reflected the dysfunction of PS under ozone stress. This data confirmed that the $\mathrm{O}_{3}$ impacts were different depending on the crop developmental stage and the $\mathrm{O}_{3}$ concentration. With regard to the recovery process, the photosynthetic depression was not the permanent process under the acute $\mathrm{O}_{3}$ exposure. Further research for the long-term $\mathrm{O}_{3}$ exposure is necessary to determine the injury level and the recovery potential of tomato.

longterm ozone exposure on citrus: Chlorophyll $a$ fluorescence and gas exchange. - Photosynthetica 44: 548-554, 2006.

Calatayud, V., García-Breijo, F.J., Cervero, J. et al.: Physiological, anatomical and biomass partitioning responses to ozone in the Mediterranean endemic plant Lamottea dianae. Ecotox. Environ. Safe. 74: 1131-1138, 2011.

Carrasco-Rodriguez, J.L., del Valle-Tascon, S.: Impact of elevated ozone on chlorophyll $a$ fluorescence in field-grown oat (Avena sativa). - Environ. Exp. Bot. 45: 133-142, 2001.

Chen, Z., Wang, X.K., Feng, Z.Z. et al.: Effects of elevated ozone on growth and yield of filed grown rice in Yangtze River Delta, China. - J. Environ. Sci.-China. 20: 320-325, 2008.

Contran, N., Paoletti, E.: Visible foliar injury and physiological response to ozone in Italian Provenances of Fraxinus excelsior and F. ornus. - Sci. World J. 7: 90-97, 2007.

Dann, M.S., Pell, E.J.: Decline of activity and quantity of ribulose bisphosphate carboxylase/oxygenase and net photosynthesis in ozone-treated potato foliage. - Plant Physiol. 91: 427-432, 1989.

Degl'Innocenti, E., Guidi, L., Soldatini, G.F.: Characterisation of 
the photosynthetic response of tobacco leaves to ozone: $\mathrm{CO}_{2}$ assimilation and chlorophyll fluorescence. - J. Plant Physiol. 159: $845-853,2002$ a.

Degl'Innocenti, E., Guidi, L., Soldatini, G.F.: Effect of chronic $\mathrm{O}_{3}$ fumigation on the activity of some Calvin cycle enzymes in two poplar clones. - Photosynthetica 40: 121-126, $2002 \mathrm{~b}$.

Evans, L.S., Albury, K., Jennings, N.: Relationships between anatomical characteristics and ozone sensitivity of leaves of several herbaceous dicotyledonous plant species at Great Smoky Mountains National Park. - Environ. Exp. Bot. 36: 413420, 1996.

Ferdinand, J.A., Fredericksen, T.S., Kouterick, K.B., Skelly, J.M.: Leaf morphology and ozone sensitivity of two open pollinated genotypes of black cherry (Prunus serotina) seedlings. - Environ. Pollut. 108: 297-302, 2000.

Fredericksen, T.S., Joyce, B.J., Skelly, J.M. et al.: Physiology, morphology, and ozone uptake of leaves of black cherry seedlings, saplings, and canopy trees. - Environ. Pollut. 89: 273-283, 1995.

Fredericksen, T.S., Skelly, J.M., Snyder, K.R. et al.: Predicting ozone uptake from meteorological and environmental variables. - J. Air Waste Manage. 46: 464-469, 1996.

Glick, R.E., Schlagnhaufer, C.D., Arteca, R.N., Pell, E.J.: Ozoneinduced ethylene emission accelerates the loss of ribulose-1,5bisphosphate carboxylase/oxygenase and nuclear-encoded mRNAs in senescing potato leaves. - Plant Physiol. 109: 891898, 1995.

Goumenaki, E., Taybi, T., Borland, A., Barnes, J.: Mechanisms underlying the impacts of ozone on photosynthetic performance. - Environ. Exp. Bot. 69: 259-266, 2010.

Guidi, L., Nali, C., Ciompi, S. et al.: The use of chlorophyll fluorescence and leaf gas exchange as methods for studying the different response to ozone of two bean cultivars. - J. Exp. Bot. 48: 173-179, 1997.

Hill, A.C., Littlefield, N.: Ozone. Effects on apparent photosynthesis, rate of transpiration and stomatal closure in plants. Environ. Sci. Technol. 3: 52-56, 1969.

Hill, A.C., Heggestad, H.E., Linzon, S.N.: Ozone. - In: Jacobson, J.S., Hill, A.C. (ed.): Recognition of Air Pollution Injury to Vegetation: A Pictorial Atlas. Air Pollut. Control Ass., Pittsburgh 1970.

Iacono, F., Sommer, K.J.: Response of electron transport rate of water stress-affected grapevines: Influence of leaf age. - Vitis 39: 137-144, 2000.

Iriti, M., Belli, L., Nali, C. et al.: Ozone sensitivity of currant tomato (Lycopersicon pimpinellifolium), a potential bioindicator species. - Environ. Pollut. 141: 275-282, 2006.

Kasana, M.S.: Sensitivity of three leguminous crops to $\mathrm{O}_{3}$ as influenced by different stages of growth and development. Environ. Pollut. 69: 131-149, 1991.

Kharel, K., Amgain, L.P.: Assessing the impact of ambient ozone on growth and yield of crop at Ramput, Chitwan. - J. Agric. Environ. 11: 40-45, Technical Paper, 2010.

Kolb, T.E., Fredericksen, T.S., Steiner, K.C., Skelly, J.M.: Issues in scaling tree size and age responses to ozone: A review. Environ. Pollut. 98: 195-208, 1997.

Laisk, A., Kull, O., Moldau, H.: Ozone concentration in leaf intercellular air spaces is close to zero. - Plant Physiol. 90: 1163-1167, 1989

Leipner, J, Oxborough, K, Baker, N.R.: Primary sites of ozoneinduced perturbations of photosynthesis in leaves: identification and characterization in Phaseolus vulgaris using high resolution chlorophyll fluorescence imaging. - J. Exp. Bot. 52:
1689-1696, 2001.

LI-6400 / LI-6400XT.: Portable photosynthesis system. Version 6.1, LI COR Biosciences, Inc. Lincoln, Nebraska, 2008.

Lyons, T.M., Barnes, J.D.: Influence of plant age on ozone resistance in Plantago major. - New Phytol. 138: 83-89, 1998.

Lyons, T., Ollerenshaw, J.H., Barnes, J.D.: Impacts of ozone on Plantago major: apoplastic and symplastic antioxidant status. - New Phytol. 141: 253-263, 1999.

McKee, I.F., Farage, P.K., Long, S.P.: The interactive effects of elevated $\mathrm{CO}_{2}$ and $\mathrm{O}_{3}$ concentration on photosynthesis in spring wheat. - Photosynth. Res. 45: 111-119, 1995.

Mina, U., Kumar, P., Varshney, C.K.: Effects of ozone exposure on growth, yield and isoprene emission from tomato (Lycopersicon esculentum L.) plants. - Veget. Crop Res. Bull. 72: 35-48, 2010.

Moore, R., Clark, W.D., Kingsley, R.S., Vodopich, D.: Electron transport in photosynthesis. - In: Moore, R. (ed.): Botany. William C. Brown Pub., Dubuque, Iowa 1995. Online book (http://hyperphysics.phy-astr.gsu.edu/hbase/ biology/psetran.html\#c1) (Accessed on 4 April 2012)

Nighat, F., Mahmooduzzafar., Iqbal, M.: Stomatal conductance, photosynthetic rate, and pigment content in Ruellia tuberose leaves as affected by coal-smoke pollution. - Biol. Plantarum 43: 263-267, 2000

Ort, D.R., Baker, N.R.: A photoprotective role for $\mathrm{O}_{2}$ as an alternative electron sink in photosynthesis? - Curr. Opin. Plant Biol. 5: 193-198, 2002.

Paoletti, E., Grulke, N.E.: Ozone exposure and stomatal sluggishness in different plant physiognomic classes. Environ. Pollut. 158: 2664-2671, 2010.

Pressman, E., Bar-Tal, A., Shaked, R., Rosenfeld, K.: The development of tomato root system in relation to the carbohydrate status of the whole plant. - Ann. Bot. 80: 533538, 1997.

Reich, P.B.: Quantifying plant response to ozone: a unifying theory. - Tree Physiol. 3: 63-91, 1987.

Reinert, R.A., Henderson, W.R.: Foliar injury and growth of tomato cultivars as influenced by ozone dose and plant age. J. Am. Soc. Hortic. Sci. 105: 322-324, 1980.

Ritchie, R.J.: Fitting light saturation curves measured using modulated fluorometry. - Photosynth. Res. 96: 201-215, 2008.

Robinson, M.F., Heath, J., Mansfield, T.A.: Disturbances in stomatal behaviour caused by air pollutants. - J. Exp. Bot. 49: 461-469, 1998

Sage, R.F., Reid, C.D.: Photosynthetic response mechanisms to environmental change in $\mathrm{C}_{3}$ plants. - In: Wilkinson, R.E. (ed.): Plant-Environment Interactions. Pp. 413-436. Marcel Dekker, New York - Basel - Hong Kong 1994.

Saitanis, C.J., Karandinos, M.G.: Effects of ozone on tobacco (Nicotiana tabacum L.) varieties. - J. Agron. Crop Sci. 188: 51-58, 2002.

SAS Institute: SAS STAT user's guide, version 9.2. SAS Institute Inc., Cary 2007.

Sharkey, T.D., Bernacchi, C.J., Farquhar, G.D., Singsaas, E.L.: Fitting photosynthetic carbon dioxide response curves for $\mathrm{C}_{3}$ leaves. - Plant Cell Environ. 30: 1035-1040, 2007.

Singh, E., Tiwari, S., Agrawal, M.: Effects of elevated ozone on photosynthesis and stomatal conductance of two soybean varieties: a case study to assess impacts of one component of predicted global climate change. - Plant Biol. 11: 101-108, 2009.

Thornley, J.H.M.: Dynamic model of leaf photosynthesis with acclimation to light and nitrogen. - Ann. Bot. 81: 421-430, 1998. 
Thwe, A.A., Vercambre, G., Gautier, H. et al.: Dynamic shoot and root growth at different developmental stages of tomato (Solanum lycopersicum Mill.) under acute ozone stress. - Sci. Hortic. 150: 317-325, 2013.

UNECE: Hemispheric Transport of Air Pollution: Part A: Ozone and Particulate Matter. Air Pollution Studies 17: 1-275, 2010 (http://www.htap.org/activities/2010

Final_Report/HTAP\%202010\%20Part\%20A\%20110407.pdf).

Wellburn, F.A.M., Wellburn, A.R.: Variable patterns of antioxidant protection but similar ethene emission differences in several ozone-sensitive and ozone-tolerant plant selections. - Plant Cell Environ. 19: 754-760, 1996.

Wieser, G., Tegischer, K., Tausz, M. et al.: Age effects on Norway spruce (Picea abies) susceptibility to ozone uptake: a novel approach relating stress avoidance to defense. - Tree Physiol. 22: 583-590, 2002.

Yan, K., Chen, W., He, X.Y. Zhang, et al.: Responses of photosynthesis, lipid peroxidation and antioxidant system in leaves of Quercus mongolica to elevated ozone. - Environ. Exp. Bot. 69: 198-204, 2010. 